\title{
Crack-healing in cementitious material to improve the durability of structures: Review
}

\author{
Hassan Amer Ali Algaifi ${ }^{1,2}$, Suhaimi Abu Bakar ${ }^{1,2}$, Abdul Rahman Mohd. Sam ${ }^{1,2}$, and Ahmad \\ Razin Zainal Abidin ${ }^{1}$ \\ ${ }^{1}$ Department of Structure and Materials, Faculty of Civil Engineering, UTM, 81310 Skudai, Johor \\ Bahru \\ ${ }^{2}$ UTM Construction Research Centre, Institute for Smart Infrastructure and Innovative Construction, \\ Faculty of Civil Engineering, UTM, 81310 Skudai, Johor Bahru
}

\begin{abstract}
One of the most commonly used materials in the field of construction is concrete. Nevertheless, there are strong inclinations for concrete to form cracks, which would then allow the penetration of both aggressive and harmful substances into the concrete. Subsequently, this will decrease the durability of the affected structures. Thus, the ability for cracks to heal themselves in the affected cementitious materials is in demand to prolong the life of any structure. Autogenous self-healing is one approach to overcome smaller crack widths (macrocracks). Nowadays, crack widthhealing is of great importance. Having said that, both polymers and bacteria are the most common approach to enhance autogenous self-healing and bond crack faces. Crack width-healing of up to $0.97 \mathrm{~mm}$ was achieved via bacteria-based self-healing. In this paper, the mechanisms of these approaches and their efficiency to heal crack were highlighted. Both bacteria- and polymers-based self-healing are promising techniques for the future. However, long term studies are still required before real applications can be made.
\end{abstract}

\section{Introduction}

One of the most extraordinary aspects of biological systems is the capacity to heal wounds. Concentrating on the affected areas, both leukocytes and thrombocytes are able to counter wounds, and thus commencing the healing process. Mirroring this, self-healing materials include various materials that are able to mend their functionality upon dealing with damage. These include concrete and polymer.

In particular, concrete is fundamentally brittle, and thus are susceptible to form microcracks. This drawback of concrete therefore encourages the propagation of cracks inside the concrete matrix to increase due to, for example, shrinkage cracks, drying shrinkage, expensive chemical reaction and external load [1].

\footnotetext{
* Corresponding author: enghas78@gmail.com
} 
Furthermore, on top of both the porosity and interconnectivity of pores in concrete, applied stress across time causes the microcracks to be interconnected. Subsequently, the permeability of the concrete increases significantly [2]. This affects both the strength and durability of concrete structures [3]. It will allow the penetration of water, chlorides and other harmful agents for concrete structures that are exposed to water [4].

One of the solutions to extend the lifespan of the structure is to repair cracks manually, however, it has several drawbacks such as difficult-to-access locations, short period of time (10 to 15 years) and high cost [5]. Therefore, self-healing concrete is required. Previous researchers have shown that only macrocracks of up to $0.3 \mathrm{~mm}$ can be completely sealed through the carbonation of dissolved calcium hydroxide or the hydration of unhydrated cement particles, which is the best known autogenous self-healing [6]. Alternatively, a novel approach is in demand to promote autogenous self-healing. For instance, the most common method to attain successful self-healing is by applying polymers or microorganisms. Furthermore, a microbial self-healing technique also presents several other benefits including its possibility to last for a longer period of time and both fast and active crack repair properties, however, it is still in their infancy. In addition, it is also environmentally friendly.

Moreover, the potential of calcite precipitating bacteria for crack remediation was investigated in a number of published studies; however, the bacteria were only externally applied on target samples [7-9]. Later on, Jonkers and coworkers were the first researchers, who proposed the use of bacteria directly in concrete to induce limestone precipitation, to heal concrete crack by adding the bacteria directly with their nutrient into the concrete mix without human intervention [10-13].

More recently, researchers have identified a new technique to capture bacteria as a selfhealing agent with the purpose of protecting the microorganisms from the cement paste's high $\mathrm{pH}$ environment and prolonged cement hydration which consequently results in smaller matrix pore diameters (compared to the $1 \mu \mathrm{m}$ sized bacterial spores).

Presently, the issue revolving around the capacity of self-healing technique to effectively and efficiently seal crack widths are still very much significant. To date, the maximum crack width of $0.97 \mathrm{~mm}$ can be completely healed using Bacillus sphaericus, about four times that of the non-bacteria sample [14]. This paper provides a review on different strategies to attain crack-healing in concrete as investigated by several past studies (not comprehensive) as guide for future uptake biocement. These strategies have been presented in detail in the next sections.

\section{Crack-healing in concrete}

\subsection{Autogenous self-healing in Concrete}

The ability of concrete to heal cracks or fissures by itself in the presence of water without any self-healing agent such as bacteria or polymers is well known as autogenous self-healing process. This natural process was observed in old concrete structures that come into contact with water by the French Academy of Science in $1836[15,16]$. Later, it was reasoned that it was due to two main mechanisms in different studies. Firstly, further hydration of unhydrated cement particles was detected in the cracked specimens with a variety of crack widths, in which were immersed in water $[17,18]$. Secondly, the carbonation of dissolved calcium hydroxide was found to be the sole reason of the autogenous healing of the crack, as shown in Fig.1 [19, 20]. 


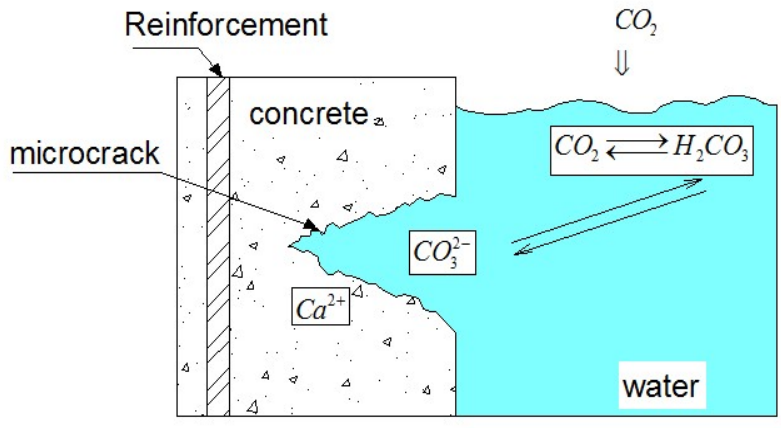

Fig. 1. Autogenous crack-healing due to the carbonation of dissolved calcium hydroxide.

The basic mechanism of carbonation of calcium hydroxide is described in Eq.1. Owing to the fact that are plenty calcium carbonate and its compatibility with cementitious compositions, calcium carbonate has been singled out as the most applicable and adaptable fillers to fill the voids, porosities and cracks in concrete.

$$
\mathrm{Ca}(\mathrm{OH})_{2}+\mathrm{CO}_{2} \rightarrow \mathrm{CaCO}_{3}+\mathrm{H}_{2} \mathrm{O}
$$

In addition to the previously mentioned, both the swelling of matrix and blocking of crack as a result of contaminations in the water as well as loose concrete particles (from crack spalling) have been identified as a possible way to fill cracks and increase the effectiveness of autogenous self-healing, as shown in Fig.2 [20]. However, it is believed that these effects have a lower value, compared to the first two main mechanisms.
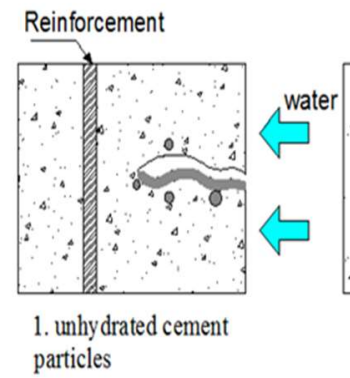
2. carbonation of dissolved calcium hydroxide

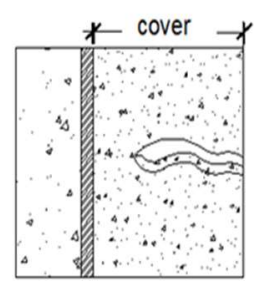

3.swelling of concrete matrix

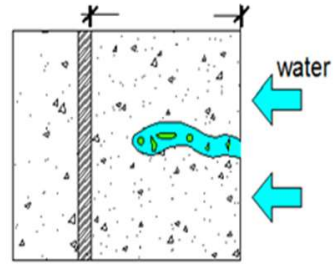

4. blocking of crack by contaminations

Fig. 2. Four mechanisms of autogenous crack-healing in cementitious materials.

\subsection{Polymer-based crack-healing}

The hardening of chemical compounds, which mainly relies on the polymerisation action in cracks, also possesses the potential to bond cracks and these chemicals are termed as adhesive agents. These chemical compounds can be either a one component or multi-component agents based on the properties of the agents. The main concept of self-healing concerns either a microcapsule or tubes (vessel), which is embedded in the concrete specimens with healing agents, as shown in Fig.3. When the vessel is hit by the cracks, it will break, which then leads to the release of the healing agents via capillary action. Subsequently, polymerisation is activated, resulting in the closing of the cracks. Recently, many researchers have utilised numerous adhesive agents for self-healing in cementitious material such as 
methylmethacrylate (MMA), epoxy resin, cyanoacrylate and polyurethane, which are further discussed in the subsequent sections.

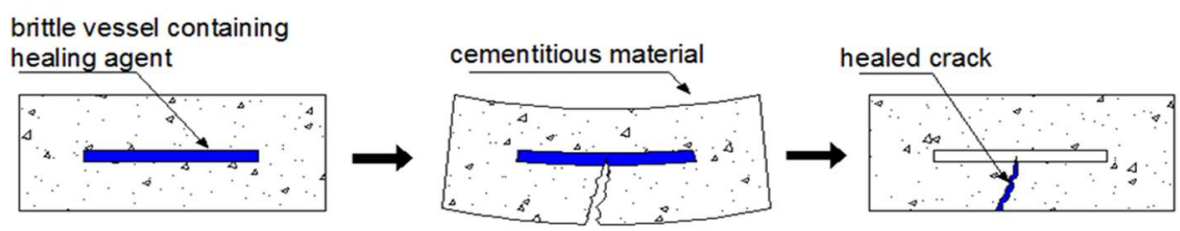

Fig. 3. Mechanism of Polymer-based crack-healing in cementitious materials (This figure reproduced from [21]).

\subsubsection{Methylmethacrylate (MMA)}

Methylmethacrylate (MMA) was applied as an adhesive agent that can be utilised for cracks self-healing. Back in 1994, this was first suggested by Dry; but the topic did not take off until White (2001) published a paper relating to the topic. It was found that the polymerisation of MMA in the pores and cracks of concrete decreased permeability and there was also an increase in strength recovery for the healed samples [22]. In addition, Methylmethacrylate monomer MMA and triethylborane, serving as catalyst, were also microencapsulated using silica gel shell [23].This is dissimilar to the research by Van Tittelboom et al. (2011a), who utilised cylindrical capsules to encapsulate two components of healing agents, which served as the initiator and activator. They found that there was a decrease in permeability due to the triggering polymerization, which resulted in filled cracks.

\subsubsection{Epoxy resin}

Another type of adhesive agents which is known as epoxy resin have been carried out to measure the effectiveness of two different epoxy resin components for self-healing and to evaluate the different encapsulation techniques (microcapsule and hollow glass tube) [24]. Initial test results showed that the microcapsule technique was not sufficient to heal the cracks due to the quantity of healing agent to be delivered into the cracks that was limited. Later, the use of hollow glass tube connected to the external delivery system (reservoir), which provide an ongoing supply, was investigated. The results showed that the improvement of strength recovery in samples containing the healing agents was not fully detected due to the insufficient mixing of the two epoxy components. In addition, the authors demonstrated that the ability of self-healing could be improved with crack widths of less than $0.5 \mathrm{~mm}$.

Furthermore, it was ascertained that more effective self-healing can be achieved through a one-component epoxy that was inserted into concrete using sealed glass tube. Being exposed to the air, the epoxy hardened, and thus repaired the cracks effectively. Nevertheless, Thao et al. (2009) indicated that the ability to randomly distribute the capsules in large scales remains as a drawback. Recently, Sam et al. (2015) have confirmed that mortar included epoxy resin without hardener is dense and less porous. It was found that epoxy resin responded well with hydroxyl ions when repairing and healing the cracks inside the specimens, and this was achievable without external intervention [25]. 


\subsubsection{Cyanoacrylate}

A cyanoacrylate (superglue) which has a low viscosity was also evaluated in term of crack closing [26]. They demonstrated that the release of superglue were attributed to the capillary action and the crack width should be smaller than the inner hollow fiber diameter to effectively actuation. Moreover, some specimens also shown regained stiffness upon loading and investigation detected that the superglue had started to harden inside the glass tube before releasing. The same concept was utilised to assess the healing ability of glass capillary tubes carrying cyanoacrylate (superglue) through mechanical strength recovery for beam concrete specimens subjected to three-point bending test [21]. They found that the leaking of the healing agent into the crack was limited due to the high capillary force in the glass tubes, which was later resolved by increasing the length of the tube with an opened-end. They also highlighted that there was an increase of the ultimate load, compared with the control specimen, and thus confirming the gained strength, as shown in Fig.4.

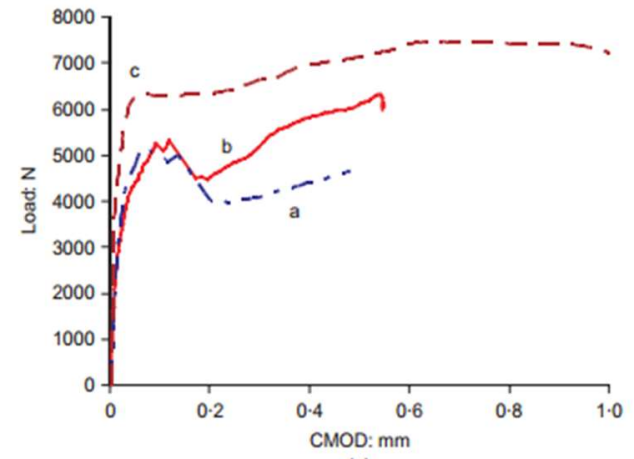

(a)

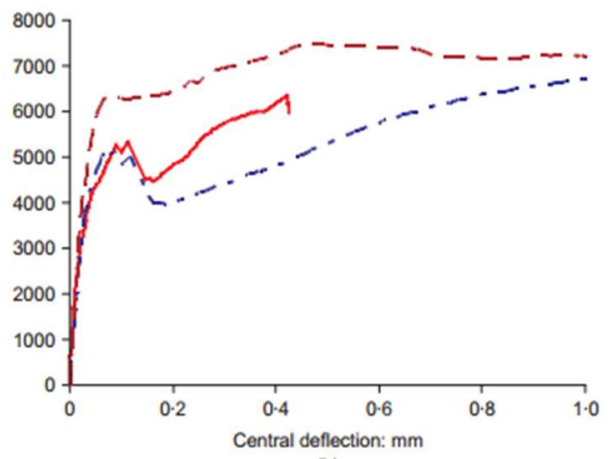

(b)

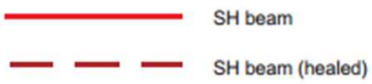

Fig. 4. (a) The load-crack mouth opening displacement CMOD; (b) The load-central deflection in beam [21].

Furthermore,Van Tittelboom and De Belie (2010) also conducted experimental work on the properties of cyanoacrylate and its efficiency. They found that the superglue had the tendency to harden (polymerisation) inside the glass tube before the cracking of the cementitious matrix. As such, they proposed the use of two encapsulation healing agent separately. The self-healing potential was then evaluated in terms of the strength recovery of the cracked specimen. Results showed grounds to support the use of superglue as a potential self-healer [27].

\subsubsection{Polyurethane}

Two components of Polyurethane was also embedded as a healing agent in self-healing concrete [6]. Tested under three-point-bending and splitting tests to create cracks, final crack widths of 0.22 and $0.25 \mathrm{~mm}$ were achieved, respectively. Later, the results show that polyurethane foam was developed, and subsequently sealed the cracks.

In addition, the healing efficiency of the samples were evaluated by reloading all samples in three-point-bending and subjecting the samples to a water permeability test. The results 
showed that higher strength and stiffness recovery values were obtained. It was also observed that more than $50 \%$ of the initial strength could be recovered after self-healing.

Despite the advantages, effectiveness and ability of polymer materials in sealing cracks (as was illustrated in previous research), several drawbacks remain, and they should be discussed and studied so as to overcome them. One of the weaknesses is the limitation of the healing agent inside the concrete since the mechanical properties can be negatively affected by increasing the vessels containing the healing agent inside the concrete matrix. Secondly, the strength of the vessel is a concern as higher strength means that the vessel would not break after the initiation of the cracks, and thus inhibits the healing process. Thirdly, the vessel should be able to resist the harsh environment of concrete during the mixing process to protect it from breaking. Finally, the polymer material is not of environmental friendly material.

\subsection{Bacteria-based crack-healing}

Bioconcrete is another self-healing technique to block cracks in concrete structures by inducing calcite carbonate precipitation through biomineralisation. The basic mechanism is that when concrete crack occurs, water will then leak via the formed cracks and the capillary pores of concrete. Consequently, with water and nutrients, the spores of the bacteria will germinate, and thus limestone will develop on the crack due to a chemical reaction of target material in the presence of bacteria, thereby sealing it up.

Furthermore, the most common microorganisms used to fill cracks in concrete or mortar by the formation of limestone are through the oxidation of organic acids, the hydrolysis of urea and the oxidation of organic carbon by nitrate reduction bacteria.

\subsubsection{Hydrolysis of urea}

Urease-positive microorganism are able to produce limestone and heal cracks in concrete or mortar through the hydrolysis of urea and in the presence of calcium which are well known as ureolytic bacteria as shown in Fig.5. The said process is stirred by natural biological healing. In that sense, the healing agents (urea and calcium) are deployed as blood platelet, which stops the bleeding by developing a clot in the damaged skin.

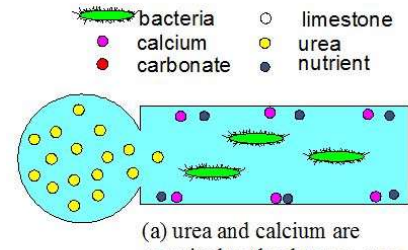

recruited to the damage area

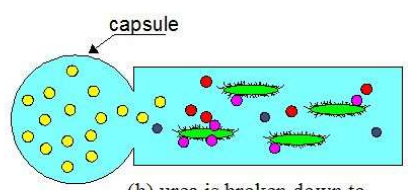

(b) urea is broken down to carbonate and calcium stick on the cell wall of bacteria

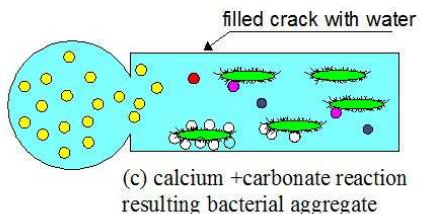

(c) calcium +carbonate reactio
resulting bacterial aggregate

Fig. 5. Evolution of closing the crack in different stages.

Specifically, the process works because the bacteria releases urease enzyme, which in turn catalyses the decomposition of urea to ammonium and carbonate. The concentration of carbonate increases in the bacterial environment. Following that, the $\mathrm{Ca}^{2+}$ ions would respond with the $\mathrm{CO}_{3}^{-2}$ ions. Ultimately, this results in the precipitation of $\mathrm{CaCO}_{3}$ at the cell surface 
of bacteria leading to form large bacterial aggregate over time [28]. This process can be summarized in Eq. 2:

$$
\mathrm{CO}\left(\mathrm{NH}_{2}\right)_{2}+2 \mathrm{H}_{2} \mathrm{O}+\mathrm{Ca}^{+2} \stackrel{\text { urease }}{\longrightarrow} 2 \mathrm{NH}_{4}^{+}+\mathrm{CaCO}_{3}(s)+2 \mathrm{Cl}^{-}
$$

Furthermore, the ability of the bacteria to seal crack through the hydrolysis of urea and improve the strength and durability of cementitious material have been conducted and summarized as shown in Table 1.

Table 1. The function of ureolysis bacteria species in crack healing.

\begin{tabular}{|c|c|c|c|c|c|c|}
\hline bacteria & Embedded & $\begin{array}{c}\text { healing } \\
\text { agent }\end{array}$ & $\begin{array}{l}\text { Crack } \\
\text { width }\end{array}$ & $\begin{array}{l}\text { Strength } \\
\text { recovery }\end{array}$ & $\begin{array}{l}\text { Durabilit } \\
\text { y effect }\end{array}$ & References \\
\hline subtilis & $\begin{array}{c}\text { Directly with } \\
2.2 * 10^{6} \\
\text { cells } / \mathrm{ml}\end{array}$ & $\begin{array}{c}\text { Urea- } \mathrm{CaCl} l_{2} \\
\text { curing }\end{array}$ & 0.2 & - & $P$ & [29] \\
\hline subtilis & $\begin{array}{l}\text { Diatomite } \\
\text { Lam Dong }\end{array}$ & $\begin{array}{c}\text { Urea, } \\
\mathrm{CaCl}_{2} \cdot \mathrm{H}_{2} \mathrm{O}\end{array}$ & $1-1.8$ & - & $\mathrm{P}$ & {$[30]$} \\
\hline sphaericus & $\begin{array}{c}\text { Glass tubes } \\
\text { With PU foam }\end{array}$ & $\begin{array}{c}\text { Urea, } \\
\mathrm{Ca}\left(\mathrm{NO}_{3}\right)_{2}\end{array}$ & 0.3 & $\mathrm{P}$ & - & {$[31]$} \\
\hline sphaericus & $\begin{array}{l}\text { Hydrogel- } \\
\text { encapsulated } \\
\text { spore }\end{array}$ & $\begin{array}{l}\text { Urea, yeast } \\
\text { extract, } \\
\mathrm{Ca}\left(\mathrm{NO}_{3}\right)_{2} \cdot 4 \mathrm{H}_{2}\end{array}$ & 0.5 & - & $\mathrm{P}$ & {$[32]$} \\
\hline sphaericus & $\begin{array}{c}\text { Diatomaceous } \\
\text { earth with } 10^{9} \\
\text { cell } / \mathrm{ml} \\
\end{array}$ & $\begin{array}{l}\text { Urea, yeast } \\
\text { extract, } \\
\mathrm{Ca}\left(\mathrm{NO}_{3}\right)_{2} \cdot 4 \mathrm{H}_{2}\end{array}$ & $\begin{array}{l}0.15- \\
0.17\end{array}$ & - & $\mathrm{P}$ & [33] \\
\hline sphaericus & microcapsule & $\begin{array}{c}\text { Urea, } \\
\text { calcium- } \\
\text { nitrate ,yeast } \\
\text { extract }\end{array}$ & 0.97 & - & $\mathrm{P}$ & {$[14]$} \\
\hline sphaericus & $\begin{array}{l}\text { Silica gel, } \\
\text { polyurethane }\end{array}$ & $\begin{array}{c}\text { Urea, } \\
\mathrm{Ca}\left(\mathrm{NO}_{3}\right)_{2} \cdot 4 \mathrm{H}_{2}\end{array}$ & $\begin{array}{l}0.35 \\
0.25\end{array}$ & $\mathrm{P}$ & $\mathrm{P}$ & {$[34]$} \\
\hline pasteurii & $\begin{array}{l}\text { Direct with } \\
2-6 * 10^{7} \\
\text { CFU } / \mathrm{ml}\end{array}$ & $\begin{array}{c}\text { Mixing water } \\
\text { was replaced } \\
\text { by urea-yeast } \\
\text { extract } \\
\text { medium } \\
\end{array}$ & - & $\mathrm{P}$ & $\mathrm{P}$ & {$[35]$} \\
\hline $\begin{array}{l}\text { Megaterium, } \\
\text { licheniformi } \\
\text { s, flexus }\end{array}$ & $\begin{array}{l}\text { Direct with } \\
10^{5} \text { cell } / \mathrm{ml} \text { of } \\
\text { mixing water }\end{array}$ & $\begin{array}{l}\text { Urea-broth } \\
\text { culture }\end{array}$ & $\begin{array}{c}0.3 \\
0.3 \\
-\end{array}$ & - & - & {$[36]$} \\
\hline
\end{tabular}

$\mathrm{N}$ negative effect, $\mathrm{P}$ positive effect

\subsubsection{Oxidation of organic acids}

The second mechanism of biocement is to produce calcite through the oxidation of organic acids. As expressed in Eq.3 calcium carbonate is formed with the conversion of calcium acetate during bacterial metabolism [13].

$$
\mathrm{CaC}_{6} \mathrm{H}_{10} \mathrm{O}_{6}+6 \mathrm{O}_{2}-\underline{\text { bacteria }} \longrightarrow \underset{\mathrm{CaCO}}{\longrightarrow}+5 \mathrm{H}_{2} \mathrm{O}+5 \mathrm{CO}_{2}
$$


Compared to the urea hydrolysis technique, the metabolic change of calcium lactate would not produce high amounts of ammonia that significantly raise the risks of reinforcement corrosion. As shown in Eq.4, via this metabolic way, the precipitation of calcium carbonate will also produce, which is able to react with portlandite to develop more calcium carbonate [13]. Portlandite is not an important hydration product of Portland cement.

$$
5 \mathrm{CO}_{2}+\mathrm{Ca}(\mathrm{OH})_{2} \longrightarrow 5 \mathrm{CaCO}_{3}+5 \mathrm{H}_{2} \mathrm{O}
$$

The oxidation of organic acids technique was also utilized in many previous researches. A crack width of up to $0.46 \mathrm{~mm}$ were healed after 100 days by applying two-component healing agent; calcium lactate and bacteria spores (alkalinitrilicus). This was twice the healed width of the other specimens (up to $0.18 \mathrm{~mm}$ only) [37]. Another study was pursued to establish the factors that can affect the bacteria-based self-healing method on cement paste specimens containing bacteria liquid (Spore-forming alkali-resistant) and substrate [38]. The results showed that crack widths play a great role in evaluating the ability of microbial healing agent to repair cracks by itself. With an increase of crack width, the bacteria-based self-healing declined and the opportunity to repair cracks was more difficult, as shown in Fig.6. In addition, crack widths of up to $0.3 \mathrm{~mm}$ was almost completely healed after 20 days, while it was impossible to fully heal larger width cracks (only partially healed when widths were up to $0.8 \mathrm{~mm}$ ). It was reasoned that this was due to the bacterial healing agent and calcite formation, which spreaded easily to the cracks outside. Another explanation was that the bacterial healing agent was not sufficient to fully heal larger crack widths.

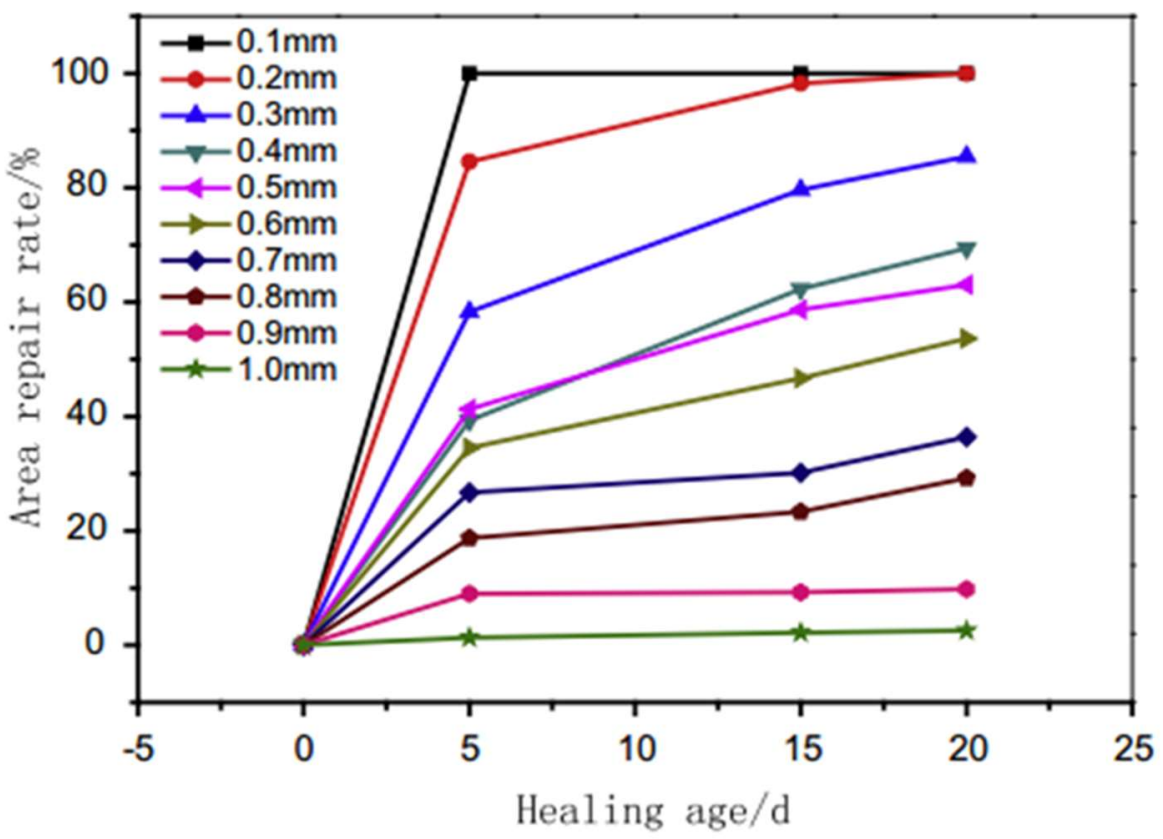

Fig. 6. Crack-healing with different widths after various periods time [38].

Moreover, curing condition and cracking age have shown their effect on the crack selfhealing. The former, There was no apparent healing in the samples under the wet curing condition, while the samples subjected to wet-dry curing and water curing had a great healing ratio, which confirmed that water is essential for self-healing concrete based on bacteria. The 
latter, the cracking age increased the crack healing ratio reduced significantly. In addition, the healing ratio of the cracks was very small when the concrete cracking age was greater than 60 days. This was consistent with data presented in previous literature. This was unsurprising as the lifespan of bacteria spores significantly reduces when they are directly included into the concrete with their food. Instead, to prolong their lifespan, they should be encapsulated or immobilizes in a protection carrier. Table 2 highlight a selected research (not comprehensive) that assess the ability of self-healing concrete through the oxidation of organic acids technique.

Table 2. The function of Oxidation of organic acids by bacteria species in crack healing.

\begin{tabular}{|c|c|c|c|c|c|c|}
\hline bacteria & Embedded & $\begin{array}{c}\text { healing } \\
\text { agent }\end{array}$ & $\begin{array}{l}\text { Crack- } \\
\text { width }\end{array}$ & $\begin{array}{l}\text { Strength } \\
\text { recovery }\end{array}$ & $\begin{array}{c}\text { Durability } \\
\text { effect }\end{array}$ & References \\
\hline non-ureolytic & $\begin{array}{c}\text { Directly with } \\
1 * 10^{7} \text { cell } / \mathrm{cm}^{3}\end{array}$ & $\begin{array}{l}\text { calcium } \\
\text { lactate, } \\
\text { calcium } \\
\text { glutamate }\end{array}$ & - & $P$ & $\mathrm{P}$ & [39] \\
\hline cohnii & $\begin{array}{c}\text { Expanded } \\
\text { perlite } \\
\text { expanded clay } \\
\text { with } \\
3.6^{*} 10^{9} \\
\text { cell } / \mathrm{ml}\end{array}$ & $\begin{array}{c}\text { Calcium } \\
\text { lactate, } \\
\text { yeast } \\
\text { extract }\end{array}$ & $\begin{array}{l}0.79 \\
0.45\end{array}$ & - & - & [40] \\
\hline subtilis & $\begin{array}{l}\text { Light weight } \\
\text { agg. } \\
\text { graphite nano } \\
\text { platelets with } \\
2.8^{*} 10^{8} \\
\text { cell } / \mathrm{ml}\end{array}$ & $\begin{array}{c}\text { Calcium } \\
\text { lactate }\end{array}$ & $\begin{array}{l}0.6 \\
0.8\end{array}$ & - & - & [41] \\
\hline cohnii & clay aggregate & $\begin{array}{c}\text { Calcium } \\
\text { lactate }\end{array}$ & 0.15 & - & $\mathrm{P}$ & {$[42]$} \\
\hline pseudofirmus & $\begin{array}{l}\text { Light weight } \\
\text { agg. }\end{array}$ & $\begin{array}{c}\text { Calcium } \\
\text { lactate }\end{array}$ & $\begin{array}{l}0.08- \\
0.22 \\
\end{array}$ & - & - & [43] \\
\hline alkalinitrilicus & Expanded clay & $\begin{array}{c}\text { Calcium } \\
\text { lactate }\end{array}$ & 0.46 & - & - & [37] \\
\hline $\begin{array}{c}\text { Spore- } \\
\text { forming } \\
\text { alkali- } \\
\text { resistance }\end{array}$ & direct & $\begin{array}{l}\text { Calcium } \\
\text { lactate }\end{array}$ & 0.48 & - & $P$ & [38] \\
\hline
\end{tabular}

$\mathrm{N}$ negative effect, $\mathrm{P}$ positive effect

\subsubsection{Organic carbon oxidation by Nitrate reduction}

The oxidation of organic carbon by reduction bacteria is another novel pathway to induce calcite precipitation which is also well known as denitrification. It is distinguished by its performance in difficult conditions such as when there is a lack of oxygen and in scenarios whereby no toxic ions are produced. In addition, the bio-chemical process of organic matter oxidation by reduction bacteria leads to the generation of nitrite which in turn plays a role as the corrosion inhibitor [44-47].

The basic mechanism of calcite precipitation by nitrate reduction bacteria is that the bacteria respires on nitrate and converts it into bicarbonate. Subsequently, the bicarbonate 
reacts with calcium ions to induce calcium carbonate , regardless of the amount of Eq.5 [48].

$$
\mathrm{Ca}(\mathrm{HCOO})_{2}+0.4 \mathrm{Ca}\left(\mathrm{NO}_{3}\right)_{2} \stackrel{\text { bacteria }}{\longrightarrow} 1.4 \mathrm{CaCO}_{3}+0.4 \mathrm{~N}_{2}+0.6 \mathrm{CO}_{2}+\mathrm{H}_{2} \mathrm{O}
$$

A maximum crack-width that could be healed by reduction bacteria was $0.48 \mathrm{~mm}$ in 56 days in mortar mixture by introducing diaphorobacter nitroreducens and pseudomonas aeruginosa immobilized bacteria as a self-healing additives [45]. Moreover, a regain of $85 \%$ of water tightness was attained after 56 days for crack width of $0.465 \mathrm{~mm}$.

\section{Conclusion}

Reinforced concrete structures should be designed to be smart enough to identify any damage and repair itself, which would have a significant potential to extend their service life and reduce their social, environmental and economic costs. From this point of view, the whole society would benefit from self-healing concrete structures. Autogenous self-healing is suitable for crack width of up to $0.3 \mathrm{~mm}$. Recently, much attention has been focused on selfhealing concrete using bacteria and polymer. Through the application of bacteria-based selfhealing, crack width of up to $0.97 \mathrm{~mm}$ can be healed. As such, both bacteria and polymers have been identified as encouraging ingredients of self-healing techniques. However, Crackhealing is still a developing procedure and has not evolved to a fully-fledged solution to inhibit cracking in concrete. In addition, numerical model to simulate self-healing concrete is required to reduce the cost of experimental works and time.

\section{References}

1. A. Ammouche, J. Riss, D. Breysse,J. Marchand, Cement and concrete composites, 23, 267 (2001)

2. N. Banthia, A. Biparva,S. Mindess, Cement and Concrete Research, 35, 1651 (2005)

3. V. Picandet, A. Khelidj,H. Bellegou, Cement and Concrete Research, 39, 537 (2009)

4. M. Choinska, A. Khelidj, G. Chatzigeorgiou,G. Pijaudier-Cabot, Cement and Concrete Research, 37, 79 (2007)

5. K. Van Breugel. in Proceedings of the first international conference on self-healing materials, 1 (2007)

6. K. Van Tittelboom, N. De Belie, D. Van Loo,P. Jacobs, Cement and Concrete Composites, 33, 497 (2011)

7. S.S. Bang, J.K. Galinat,V. Ramakrishnan, Enzyme and microbial technology, 28, 404 (2001)

8. N. De Belie,W. De Muynck. in Proceedings of the International Conference on Concrete Repair, Rehabilitation and Retrofitting (ICCRRR), Cape Town, South Africa, 291 (2008)

9. S.K. Ramachandran, V. Ramakrishnan,S.S. Bang, ACI Materials Journal-American Concrete Institute, 98, 3 (2001)

10. H. Jonkers, Self Healing Materials, 195 (2008)

11. H.M. Jonkers,E. Schlangen. in Proc. int. FIB symposium, 1, 425 (2008) 
12. H.M. Jonkers,E. Schlangen. in Concrete Repair, Rehabilitation and Retrofitting II: 2 nd International Conference on Concrete Repair, Rehabilitation and Retrofitting, ICCRRR2, 24-26 November 2008, Cape Town, South Africa, 8, 119 (2008)

13. H.M. Jonkers, A. Thijssen, G. Muyzer, O. Copuroglu,E. Schlangen, Ecological engineering, 36, 230 (2010)

14. J. Wang, H. Soens, W. Verstraete,N. De Belie, Cement and Concrete Research, 56, 139 (2014)

15. C. Clear, The effects of autogenous healing upon the leakage of water through cracks in concrete, 1985.

16. N. Hearn, Materials and Structures, 31, 563 (1998)

17. H. Huang, G. Ye,D. Damidot, Cement and Concrete Research, 52, 71 (2013)

18. S. Jacobsen, J. Marchand,H. Hornain, Cement and Concrete Research, 25, 1781 (1995)

19. C. Edvardsen, ACI Mater. J, 96, M56 (1999)

20. W. Ramm,M. Biscoping, Nuclear Engineering and Design, 179, 191 (1998)

21. C. Joseph, A.D. Jefferson, B. Isaacs, R.J. Lark,D.R. Gardner, Magazine of Concrete Research, 62, 831 (2010)

22. C. Dry, Smart Materials and Structures, 3, 118 (1994)

23. Z. Yang, J. Hollar, X. He,X. Shi, Cement and Concrete Composites, 33, 506 (2011)

24. H. Mihashi, Y. KANEKO, T. Nishiwaki,K. Otsuka, Transactions of the Japan Concrete Institute, 22, 441 (2001)

25. A.R.M. Sam, N.F. Ariffin, M.W. Hussin, H. Seung, M. Samadi,J. Mirza, (2015)

26. V.C. Li, Y.M. Lim,Y.-W. Chan, Composites Part B: Engineering, 29, 819 (1998)

27. K. Van Tittelboom,N. De Belie, Int. J. 3R's, 1, 12 (2010)

28. M.O. Cuthbert, L.A. McMillan, S. Handley-Sidhu, M.S. Riley, D.J. Tobler,V.R. Phoenix, Environmental science \& technology, 47, 13637 (2013)

29. H. Kalhori,R. Bagherpour, Construction and Building Materials, 148, 249 (2017)

30. N.N.T. Huynh, N.M. Phuong, N.P.A. Toan,N.K. Son, Procedia Engineering, 171, 598 (2017)

31. J. Wang, K. Van Tittelboom, N. De Belie,W. Verstraete. in Proceedings of the second international conference on sustainable construction materials and technologies, 1807 (2010)

32. J. Wang, D. Snoeck, S. Van Vlierberghe, W. Verstraete,N. De Belie, Construction and building materials, 68, 110 (2014)

33. J. Wang, N. De Belie,W. Verstraete, Journal of industrial microbiology \& biotechnology, 39, 567 (2012)

34. J. Wang, K. Van Tittelboom, N. De Belie,W. Verstraete, Construction and building materials, 26, 532 (2012)

35. S. Liu, Z.B. Bundur, J. Zhu,R.D. Ferron, Cement and Concrete Research, 83, 70 (2016)

36. S. Krishnapriya,D.V. Babu, Microbiological research, 174, 48 (2015)

37. V. Wiktor,H.M. Jonkers, Cement and Concrete Composites, 33, 763 (2011)

38. M. Luo, C. Qian, R. Li,H. Rong, Journal of Wuhan University of Technology-Mater. Sci. Ed., 30, 1255 (2015)

39. J. Xu,W. Yao, Cement and concrete research, 64, 1 (2014) 
40. J. Zhang, Y. Liu, T. Feng, M. Zhou, L. Zhao, A. Zhou,Z. Li, Construction and Building Materials, 148, 610 (2017)

41. W. Khaliq,M.B. Ehsan, Construction and Building Materials, 102, 349 (2016)

42. H. Jonkers, Heron, 56 (1/2), (2011)

43. C. Stuckrath, R. Serpell, L.M. Valenzuela,M. Lopez, Cement and Concrete Composites, 50, 10 (2014)

44. Y.Ç. Erşan, N. De Belie,N. Boon, Biochemical Engineering Journal, 101, 108 (2015)

45. Y.Ç. Erşan, E. Hernandez-Sanabria, N. Boon,N. De Belie, Cement and Concrete Composites, 70, 159 (2016)

46. C. Glass,J. Silverstein, Water Research, 32, 831 (1998)

47. A. Królikowski,J. Kuziak, Electrochimica acta, 56, 7845 (2011)

48. Y.Ç. Erşan, H. Verbruggen, I. De Graeve, W. Verstraete, N. De Belie,N. Boon, Cement and Concrete Research, 83, 19 (2016) 